\title{
Is it feasible to construct a community profile of exposure to industrial air pollution?
}

Tanja Pless-Mulloli, Christine E Dunn, Raj Bhopal, Peter Phillimore, Suzanne Moffatt, John Edwards

\begin{abstract}
Objective-An epidemiological investigation to assess the validity of residential proximity to industry as a measure of community exposure.

Methods-19 Housing estates in Teesside (population 1991: 77 330) in north east England were grouped into zones: $A=$ near; $B=$ intermediate; $C=$ further from industry. With residential proximity of socioeconomically matched populations as a starting point a historical land use survey, historical air quality reports, air quality monitoring, dispersion modelling data, and questionnaire data, were examined.

Results-The populations in zones A, B, and $C$ were similar for socioeconomic indicators and smoking history. Areas currently closest to industry had also been closest for most of the 20th century. Historical reports highlighted the influence of industrial emissions to local air quality, but it was difficult to follow spatial pollution patterns over time. Whereas contemporary $\mathrm{NO}_{\mathrm{x}}$ and benzene concentrations showed no geographical variation, dispersion modelling of emissions (116 industrial stacks, traffic, and domestic sources) showed a gradient associated with industry. The presumed exposure gradient of areas by proximity to industry $(A>B>C)$ was evident for all of zone $A$ and most of zones $B$ and $C$.

Conclusions-It was feasible to assemble a picture of community exposure by integration of measurements from different sources. Proximity of residence was a reasonable surrogate for complex community exposure.

(Occup Environ Med 2000;57:542-549)
\end{abstract}

Keywords: exposure assessment; community exposure; industrial pollution

In environmental epidemiology studies the assessment of exposure of a population remains both an on going area of concern when interpreting results and a major methodological challenge at the design stage. This is especially the case for retrospective exposure assessment: gaps in the spatial and temporal coverage, the relative crudity of past measurement techniques, and changes in techniques are among the many problems; and exposure assessment has therefore been earmarked as an area of future research. ${ }^{12}$

To analyse the associations between exposure to industrial air pollution and the health of residents living close to industries a comprehensive picture of past and contemporary exposure is required. However, to characterise air pollution and its variability in time and space, necessitates reliance largely on data collected for different purposes - for example, to fulfil statutory obligations. In the end, a judgement has to be made on how far the chosen exposure measures are likely to reflect the exposure of the population.

Based on the study of detailed accounts of the validity and reliability of exposure measurements and a systematic analysis of differential misclassification of exposure, ${ }^{2-6}$ the criteria we used to make judgements on whether the exposure surrogate residential proximity to industry was valid were: (a) Have we been able to characterise the temporal and spatial pattern of exposure in our study areas? (b) Have we been able to disentangle industrial sources from other pollution sources? (c) Have different methods of exposure assessment complemented one another to draw an overall picture? (d) How much have the data shown about the true exposure of populations in the past? (e) Was the initial assumption and design based on proximity of industry as a surrogate for residential exposure vindicated?

Often, polluting industries are located in areas with poor populations, ${ }^{7-9}$ among whom high smoking rates, poor housing conditions, and unemployment prevail. Because these socioeconomic characteristics are strong determinants of both exposures and ill health several approaches have been developed to take them into account at the design and analysis stage of epidemiological studies. ${ }^{8}$ 10-18 $^{-1}$ We chose socioeconomically matched populations with the Townsend deprivation score and additional census variables, therefore correcting for socioeconomic influences at the design stage.

In summary, there is currently no single method of assessment of exposure that could conceptually or indeed in practice be considered as a gold standard. The question we consider in this paper is whether we can build up a useful picture of exposure of a community by combining data from various sources? We examined different methods of assessing exposure supplementing data with evidence from surveys and descriptive accounts of past pollution to create a picture of past and present exposure covering more than 40 years.

The paper arises out of an epidemiological study into the association between proximity of residence to an industrial complex and acute and chronic health outcomes. ${ }^{8}{ }^{19}$ It was evident at an early stage that due to resource and 
conceptual constraints, direct contemporary measurements of exposure would be unable to capture the complex and varying exposures in a community, let alone exposures in the past. The study design was based, therefore, on proximity of residence as a surrogate for exposure. It was then necessary to verify and validate how good a surrogate of exposure the selected areas were.

\section{Background}

The research underpinning this paper was driven by the hypothesis that populations living close to industrial operations are likely to experience greater pollution derived from the industry than those living further away. Previous research in the area had highlighted health differentials for all cause and respiratory mortality under the age of 65 in populations experiencing similar levels of socioeconomic deprivation, ${ }^{20-22}$ and differentials in exposure to air pollution were one of the possible explanations.

Teesside is an industrial conurbation with a population of over 400000 (fig 1) characterised by large petrochemical operations as well as steel and coke works, which have been continuous for 150 years. Chemicals and oil based operations developed after 1920. Although industry has tended to relocate down river, moving away from residential populations, even in the 1980s and 1990s sizeable populations still lived close to industrial operations.
The epidemiological study was based on a comparison of areas matched for socioeconomic characteristics. Neighbourhoods were grouped into near, intermediate, and further from industry reflecting the hypothesised exposure gradient. The hypothesised exposure gradient $(\mathrm{A}>\mathrm{B}>\mathrm{C})$ was taking into account that concentrations of pollution were highest when no dispersion was taking place due to low wind speeds. The focus of this paper is what kind of picture of community exposure is it possible to create in disaggregated small neighbourhoods, and how far did this picture support the assumptions of residential proximity as a surrogate for exposure?

The identification of areas of varying proximity to industry involved a stepwise process to distinguish socially homogeneous localities. ${ }^{8} 1517$ Nineteen housing estates in Teesside (in 1991 the population was 77 330) were selected. The other approaches for exposure assessment encompassed a historical land use survey, air quality monitoring including a review of historical pollution data and local authority reports, dispersion modelling, and a postal questionnaire survey.

\section{Historical land use survey}

A historical land use survey investigated the possibility that the location of industrial developments and closures affected the exposure of populations differently in the study zones. If in the past, industries had existed in areas of the study classified as intermediate or further from

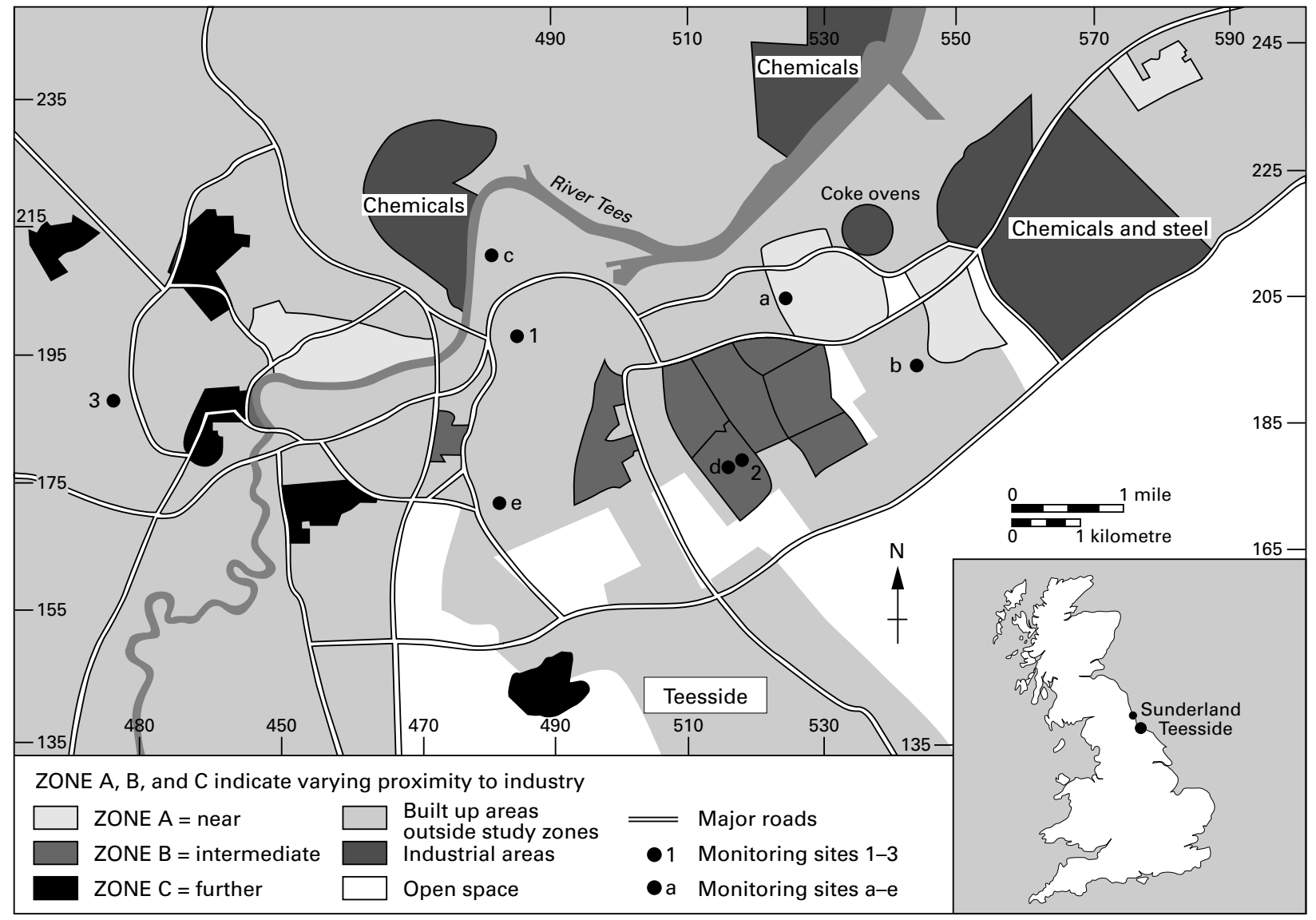

Figure 1 Housing estates in zones $A, B$, and $C$ and selected monitoring sites for smoke and $\mathrm{SO}_{2}$. 
Table 1 Land use within $500 m$ of study areas at four times

\begin{tabular}{|c|c|c|c|c|c|c|}
\hline \multirow[b]{2}{*}{ Estate No } & \multirow[b]{2}{*}{ Zone ${ }^{\star}$} & \multirow[b]{2}{*}{ Estate name } & \multicolumn{4}{|l|}{ Year } \\
\hline & & & 1900 & 1930 & 1960 & 1990 \\
\hline 1 & A & Dormanstown & $\mathrm{O}$ & $\mathrm{H}$ & $\mathrm{xx}$ & $\mathrm{xx}$ \\
\hline 2 & A & Grangetown North & $\mathrm{xX}$ & $\mathrm{xX}$ & $\mathrm{xX}$ & $\mathrm{xX}$ \\
\hline 3 & A & Grangetown South & $\mathrm{O}$ & $\mathrm{O}$ & $\mathrm{H}$ & $\mathrm{H}$ \\
\hline 4 & A & South Bank & $\mathrm{xX}$ & $\mathrm{xX}$ & $\mathrm{xX}$ & $\mathrm{H}$ \\
\hline 5 & A & Portrack and Tilery & $\mathrm{XX}$ & $\mathrm{xX}$ & $\mathrm{XX}$ & $\mathrm{X}$ \\
\hline 6 & B & Brambles Farm & $\mathrm{O}$ & $\mathrm{O}$ & $\mathrm{H}$ & $\mathrm{H}$ \\
\hline 7 & B & Thorntree & $\mathrm{O}$ & $\mathrm{O}$ & $\mathrm{H}$ & $\mathrm{H}$ \\
\hline 8 & B & Netherfields & $\mathrm{O}$ & $\mathrm{O}$ & $\mathrm{H}$ & $\mathrm{H}$ \\
\hline 9 & B & Pallister Park & $\mathrm{O}$ & $\mathrm{O}$ & $\mathrm{H}$ & $\mathrm{H}$ \\
\hline 10 & B & Berwick Hills & $\mathrm{O}$ & $\mathrm{O}$ & $\mathrm{H}$ & $\mathrm{H}$ \\
\hline 11 & B & Park End & $\mathrm{O}$ & $\mathrm{O}$ & $\mathrm{H}$ & $\mathrm{H}$ \\
\hline 12 & B & Grove Hill and Beechwood & $\mathrm{O}$ & $\mathrm{H}$ & $\mathrm{H}$ & $\mathrm{H}$ \\
\hline 13 & B & Winney Banks & $\mathrm{O}$ & $\mathrm{O}$ & $\mathrm{H}$ & $\mathrm{H}$ \\
\hline 14 & $\mathrm{C}$ & Hemlington & $\mathrm{O}$ & $\mathrm{O}$ & $\mathrm{H}$ & $\mathrm{H}$ \\
\hline 15 & $\mathrm{C}$ & Mandale & Z & $\mathrm{H}$ & $\mathrm{H}$ & $\mathrm{H}$ \\
\hline 16 & $\mathrm{C}$ & Parkfields & $\mathrm{X}$ & $\mathrm{XX}$ & $\mathrm{XX}$ & $\mathrm{H}$ \\
\hline 17 & $\mathrm{C}$ & Eastbourne and Ragworth & $\mathrm{O}$ & $\mathrm{H}$ & $\mathrm{H}$ & $\mathrm{H}$ \\
\hline 18 & $\mathrm{C}$ & Blue Hall & $\mathrm{O}$ & $\mathrm{O}$ & $\mathrm{H}$ & $\mathrm{H}$ \\
\hline 19 & $\mathrm{C}$ & Hardwick & $\mathrm{O}$ & $\mathrm{O}$ & $\mathrm{O}$ & $\mathrm{H}$ \\
\hline
\end{tabular}

*Zone: $\mathrm{A}=$ near; $\mathrm{B}=$ intermediate; $\mathrm{C}=$ further.

current industrial complexes serious exposure misclassification could have been introduced.

METHODS

A land use survey based on local government archives was carried out for four areas encompassing our study area. Official annotated Ordnance Survey maps held in local authorities and archive material were used to produce "snapshot" maps for the years 1900, 1930, 1960, and 1990. The categories and subcategories of land use for our survey were those used by local authorities to classify potentially contaminated land. ${ }^{17}$

RESULTS

Of those areas closest to industry (zone A), residential development in neighbourhood 1 (Dormanstown) began in the 1920 s on a green field site, the period after the war was marked by continued urban and industrial development (table 1). Area 3 (Grangetown South) remained purely residential, whereas areas 2 and 4 (Grangetown North and South Bank) have experienced large scale iron and steel production close to housing since 1900. Area 5 (Portrack and Tilery) had heavy industry alongside residential developments for most of the 20th century. Most of the areas defined as intermediate (zone B) or further away from industry (zone C) were green field sites until new housing estates were built. Early industrial developments were present only in three estates: Whinney Banks (area 13, zone B),

Table 2 Mean concentrations of smoke and $\mathrm{SO}_{2}$ in Teesside 1968 in summer and winter in $\mu \mathrm{g} / \mathrm{m}^{3}$ (data source ${ }^{819}$ )

\begin{tabular}{|c|c|c|c|c|c|}
\hline \multirow{2}{*}{$\begin{array}{l}\text { Site } \\
\text { code }\end{array}$} & \multirow{2}{*}{$\begin{array}{l}\text { Zone, if } \\
\text { applicablet }\end{array}$} & \multicolumn{2}{|c|}{ Smoke season } & \multicolumn{2}{|c|}{$\mathrm{SO}_{2}$ season } \\
\hline & & Winter & Summer & Winter & Summer \\
\hline a & A & 284 & 84 & 211 & 72 \\
\hline b & & 98 & 37 & 151 & 58 \\
\hline c & & 140 & 33 & 109 & 49 \\
\hline d & B & 56 & 57 & 94 & 57 \\
\hline $\mathrm{e}$ & & 56 & 32 & 64 & 45 \\
\hline
\end{tabular}

^Smoke was used as a measurement of fine suspended particulate matter $<15 \mu \mathrm{m}$ examining blackness of filters.

†Zones: $\mathrm{A}=$ near to industry; $\mathrm{B}=$ intermediate distance from industry.
Mandale (area 15, zone C), and Parkfields (area 16, zone C). Hemlington (area 14, zone C) had no housing until the late $1960 \mathrm{~s}$.

Overall, the land use survey confirmed the extent to which areas currently closest to industry had been close to industry earlier, indicating the appropriateness of areas in zone $\mathrm{A}$ and few anomalies in our definition of zones $\mathrm{B}$ and $\mathrm{C}$.

\section{Air quality monitoring}

\section{METHODS}

Air quality monitoring data were collected from the following sources: $(a)$ current routinely collected data; (b) surveys commissioned for this study; (c) historical, routinely available data from the annual reports of the medical officer of health and pollution control committee reports; and $(d)$ the national air quality archive (partly overlapping with $(a)$ and $(c)) .{ }^{17}{ }^{1923-34}$ Here we present summaries of findings for smoke, sulphur dioxide, and insoluble solids. For contemporary monitoring we chose nitrogen dioxide and benzene to allow comparisons to be made between monitored data and data from dispersion modelling. Emission data for dispersion modelling were available only for nitrogen dioxide and benzene.

\section{RESULTS}

Historical data on smoke, sulphur dioxide, and insoluble solids

From much information retrieved from historical documents it was possible to observe trends of falling levels of pollution over time, but it was difficult to follow spatial patterns over time. For example, average monthly deposits of insoluble solids showed a sharp gradient between industrial (I), semi-industrial (SI), and residential $(\mathrm{R})$ areas in tonnes per square mile: 196222 (I), 11 (SI), 6 (R); 1964, 18 (I), 9 (SI), 7 (R); 1966, 25 (I), 12 (SI), 7 (R). ${ }^{83} 33$ Table 2 summarises the variation in smoke and sulphur dioxide in 1968. The site closest to industry (a) had highest levels, while lowest levels were found well away from industry $(e)$. The high readings were in South Bank close to industrial operations, which was also frequently mentioned in local documentation as heavily polluted. ${ }^{24} 28-313536$

During the late 1970s and early 1980s the number of monitoring stations was reduced and replaced by complex real time monitoring equipment. This modern equipment allowed measurements at lower levels of pollution with high temporal resolution. However, monitoring data were no longer available across a range of sites.

Contemporary monitoring of nitrogen dioxide

The spatial resolution of monitoring points for nitrogen dioxide was not sufficient to detect localised peaks-for example near busy roads-and nitrogen dioxide concentrations were found to vary little across the 10 monitoring points in the study area in 1993 (table 3).

\section{Contemporary monitoring of benzene}

Benzene concentrations at roadsides were about double those of the urban background 
Table 3 Monitored concentrations of $\mathrm{NO}_{2}$ in Teesside (ppb)

\begin{tabular}{|c|c|c|c|c|c|c|c|c|c|}
\hline \multirow{4}{*}{$\begin{array}{l}\text { Monitor. } \\
\text { location } \\
\text { (see table 1) }\end{array}$} & \multirow[b]{4}{*}{ Zone ${ }^{\star}$} & \multirow[b]{4}{*}{ Area } & \multicolumn{7}{|c|}{ Type of monitoring } \\
\hline & & & \multirow{2}{*}{\multicolumn{2}{|c|}{$\begin{array}{l}\text { National surveyt } \\
\text { annual mean }\end{array}$}} & \multirow{3}{*}{$\begin{array}{l}\text { Study survey } 4 \\
\text { sample mean } 1993\end{array}$} & \multicolumn{4}{|l|}{ Continuous monitoring } \\
\hline & & & & & & \multirow{2}{*}{$\begin{array}{l}\text { Monthly mean of } \\
\text { hourly means } 1993-4\end{array}$} & \multirow{2}{*}{$\begin{array}{l}\text { Min-max highest } \\
\text { hourly means 1993-4 }\end{array}$} & \multicolumn{2}{|c|}{ Annual mean } \\
\hline & & & 1986 & 1991 & & & & 1993 & 1994 \\
\hline & N/A & St Hilda's & 22 & 24 & & & & & \\
\hline & N/A & Billingham & & 26 & & & & & \\
\hline & N/A & Stockton Centre & 17 & 26 & & & & & \\
\hline 17 & $\mathrm{C}$ & Ragworth Centre & 17 & 20 & & & & & \\
\hline 1 & A & Dormanstown & & & 21 & & & & \\
\hline 2 & A & Grangetown & & & 18 & $7-19$ & $32-75$ & 12 & 12 \\
\hline 4 & A & South Bank & & & 19 & & & & \\
\hline $6,8,10 \ddagger$ & $\mathrm{B}$ & East Middlesbrough & & & 18 & $7-21$ & $29-71$ & 11 & 13 \\
\hline 18 & $\mathrm{C}$ & Blue Hall & & & 20 & & & & \\
\hline 19 & $\mathrm{C}$ & Hardwick & & & 18 & & & & \\
\hline
\end{tabular}

^Zone: $\mathrm{A}=$ near; $\mathrm{B}=$ intermediate; $\mathrm{C}=$ far.

†National diffusion tube survey at six locations, ${ }^{26}$ diffusion survey carried out specifically for this study at 22 sites, covering 2 -weekly sampling on four occasions. ‡East Middlesbrough mean of locations in Brambles Farm, Netherfields, and Berwick Hill.

and about four times higher than rural backgrounds (table 4). A diffusion tube survey in 1993 assessed ambient concentrations of volatile organic compounds in the areas under study. The range of measurements for benzene (0.5-7.4 ppb) was consistent with findings of other studies. ${ }^{2526}$ Highest readings were in neighbourhoods nearest to industry. The mean in 1993 was $1.3 \mathrm{ppb}$ (London $4.6 \mathrm{ppb}$ ). ${ }^{25} 27$ Derwent et al reported analyses of many short term excursions in a time series and indicated that benzene concentrations were increased when the wind was blowing from the north east or east downwind from one major chemical complex, pointing to potentially relevant contributions. ${ }^{25}$ Another approach to assess the relative impact of airborne volatile organic compounds other than traffic is to calculate the ratio of the compound and nitrogen dioxide. ${ }^{17}$ In the 1993 diffusion tube survey the benzene/ $\mathrm{NO}_{2}$ ratio varied between 0.07 and 0.10 for all sites with the exception again of South Bank (area 4) and Grangetown (area 2) where ratios were 0.17 and 0.18 respectively, pointing to contributions from stationary sources.

\section{Dispersion modelling of emissions}

METHODS

Air quality modelling used a Gaussian plume model (US EPA's industrial source complex short term model ISCST2) to calculate mean concentrations at ground level. The model was

Table 4 Monitored concentrations of benzene in Teesside ( $p p b$ )

\begin{tabular}{|c|c|c|c|c|c|}
\hline \multirow[b]{2}{*}{$\begin{array}{l}\text { Monitoring location } \\
\text { (see table 1) }\end{array}$} & \multirow[b]{2}{*}{$\begin{array}{l}\text { Year } \\
\text { Zone }\end{array}$} & \multicolumn{4}{|c|}{ Type of monitoring } \\
\hline & & $\begin{array}{l}42 \text { Site studyt } \\
1994 \text { Range of } \\
\text { means over } \\
\text { study period }\end{array}$ & $\begin{array}{l}\text { Mean of } \\
\text { all sites }\end{array}$ & $\begin{array}{l}\text { Study } \\
\text { survey } \\
1993-4\end{array}$ & $\begin{array}{l}\text { Continuous } \\
\text { monitoring } \\
\text { 1992-3 mean } \\
\text { of } 2 y\end{array}$ \\
\hline Residential & N/A & $0.5-1.9$ & 1.2 & & \\
\hline Roadside & N/A & $1.6-2.2$ & 2.0 & & \\
\hline Industrial & N/A & $0.6-2.8$ & 1.2 & & \\
\hline Rural & N/A & N/A & 0.5 & & \\
\hline Dormanstown (1) & A & & & 1.4 & \\
\hline Grangetown (2) & A & & & 2.4 & \\
\hline South Bank (4) & A & & & 2.4 & \\
\hline \multicolumn{6}{|l|}{ East Middlesbrough } \\
\hline$(6,8,10)$ & $\mathrm{B}$ & & & 1.3 & 1.3 \\
\hline Blue Hall (18) & $\mathrm{C}$ & & & 1.6 & \\
\hline Hardwick (19) & $\mathrm{C}$ & & & 1.1 & \\
\hline
\end{tabular}

${ }^{\star}$ Zone: $\mathrm{A}=$ near; $\mathrm{B}=$ intermediate; $\mathrm{C}=$ far.

†Survey conducted by AEA Technology during a 2 week periods ${ }^{26}$; continuous monitoring was part of the national automated urban network, analysed by 25 . run for an area of $20 \mathrm{~km}$ by $15 \mathrm{~km}$ divided into a grid of 300 cells, of $1 \mathrm{~km}^{2}$ each (grid references NZ 405135 to 595135 to $\mathrm{NZ}$ 595275, fig 1) with hourly meteorological and emissions data. The model required data for atmospheric stability and mixing height, variables which are collected only at a few sites. Data from the nearest weather centre with full data was about $55 \mathrm{~km}$ north of the study area. One way to avoid the limitations of this approach would have been to compare local weather data with those from the location 55 $\mathrm{km}$ away, this was not done in this case.

For 116 industrial sources, data on stack height and diameter, gas exit temperature, gas exit velocity, and emission rate were provided by industry. Emission rates in the form of annual totals were extracted from the public register or were estimated on the basis of the mass burned for one natural gas based power station and several municipal waste and clinical incinerators. ${ }^{38}$

The model did not allow the inclusion of line sources, therefore road traffic was treated as an area source. Hourly exhaust emissions were estimated by summing the contribution from each road segment in each cell. This has been documented as a feasible option. ${ }^{39}$ Rates of emissions of oxides of nitrogen $\left(\mathrm{NO}_{\mathrm{x}}\right)$ were estimated as a function of vehicle, road, and fuel, while benzene emission rates were estimated as a function of road type only. With natural gas as the predominant domestic fuel in the study area (gas zone A: $41 \%, \mathrm{~B}: 39 \%, \mathrm{C}$ : $47 \%$; coal zone A: $1 \%$, B: $1 \%$, C: $1 \%$ ) domestic emissions were also treated as area sources. The total emission for each grid cell was estimated as the product of the average emission per household and the number of households in the cell from the 1991 census of population.

\section{RESULTS}

The average $\mathrm{NO}_{\mathrm{x}}$ concentration across the study area was estimated at $13.2 \mathrm{ppb}$, and the maximum value was predicted at $26.9 \mathrm{ppb}$ within the area of a major chemical complex (fig $2 \mathrm{~A}, \mathrm{NZ}$ 585215). Estimated concentrations were low with slightly higher values in the vicinities of two major chemical works. The model predicted an annual mean of $0.3 \mathrm{ppb}$ for 

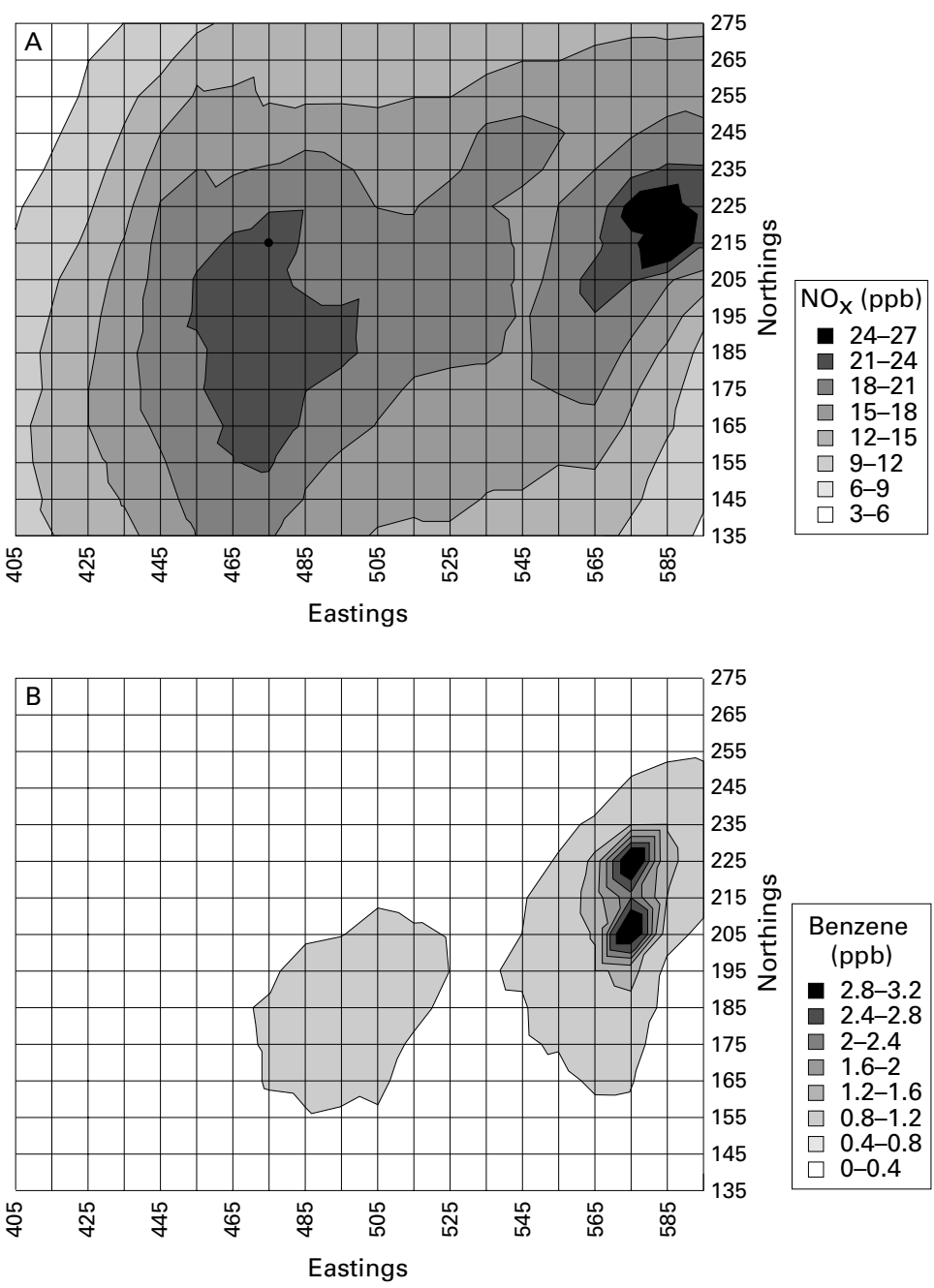

Figure 2 (A) Modelled annual mean NOx concentrations ( $p p b$ ) 1993. (B) Modelled annual mean benzene concentrations (ppb) 1993.

benzene with slightly higher values in Middlesbrough town centre; the maximum of $3.0 \mathrm{ppb}$ occurred in the area of a chemical works (fig 2 B, NZ 575205).
Table 5 shows the modelled annual mean contributions for the 19 study areas. A gradient of concentrations of $\mathrm{NO}_{x}$ attributable to industrial activities was found, with greatest relative contributions in areas closest to industry. Concentrations of $\mathrm{NO}_{\mathrm{x}}$ in area 13 (Winney Banks, zone B) were higher than expected, this may be accounted for by proximity to a busy road interchange.

For benzene, industrial contributions to total concentrations were highest in area 1 (Dormanstown). Contributions of non-industrial sources for benzene varied only by a factor of about 3, whereas the contribution from industry varied by a factor of almost 30 . An overall geographical gradient across estates was therefore apparent. Variations in total benzene concentration across the region were greater than for $\mathrm{NO}_{\mathrm{x}}$. Monitored and modelled concentrations of benzene and nitrogen dioxide agreed well.

Indoor exposure, occupational exposure, and perception of exposure

As well as monitoring and modelling we incorporated evidence of people's own perceptions about pollution in living and working conditions. On the face of it such data may seem too limited in themselves. However, we think that they assist in building up a comprehensive picture of population exposure.

METHODS

Of the 19 housing estates in Teesside, 12 (population 52 373) were the basis for a postal community survey. The questionnaire included items on socioeconomic circumstances, personal behaviour, health, and perception of risk factors influencing health. ${ }^{815} 17$

RESULTS

Data from the 1991 census and the postal survey showed that study areas experienced similar levels of socioeconomic deprivation. ${ }^{815} 17$ Table 6 shows selected data about living

Table 5 Modelled mean annual $\mathrm{NO}_{x}$ and benzene concentrations 1993 in study areas (ppb)

\begin{tabular}{|c|c|c|c|c|c|c|c|c|c|c|}
\hline \multirow{3}{*}{$\begin{array}{l}\text { Estate } \\
\text { No }\end{array}$} & \multirow[b]{3}{*}{ Zone * } & \multirow[b]{3}{*}{ Estate name } & \multicolumn{6}{|c|}{ Concentration } & \multirow{2}{*}{\multicolumn{2}{|c|}{$\begin{array}{l}\text { Industrial } \\
\text { contribution (\%) }\end{array}$}} \\
\hline & & & \multicolumn{2}{|c|}{ Due to industry } & \multicolumn{2}{|c|}{ Due to other sources } & \multicolumn{2}{|l|}{ Total } & & \\
\hline & & & $N O_{x}$ & Benzene & $N O_{x}$ & Benzene & $N O_{x}$ & Benzene & $N O_{x}$ & Benzene \\
\hline 1 & A & Dormanstown & 10 & 0.6 & 9 & 0.2 & 19 & 0.8 & 54 & 75 \\
\hline 2 & A & Grangetown North & 5 & 0.1 & 10 & 0.3 & 15 & 0.4 & 31 & 34 \\
\hline 3 & A & Grangetown South & 6 & 0.2 & 10 & 0.3 & 16 & 0.5 & 38 & 48 \\
\hline 4 & A & South Bank & 6 & 0.1 & 10 & 0.3 & 16 & 0.4 & 37 & 24 \\
\hline 5 & A & Portrack and Tilery & 3 & $<0.1$ & 16 & 0.4 & 19 & 0.4 & 16 & 6 \\
\hline 6 & $\mathrm{~B}$ & Brambles Farm & 5 & 0.1 & 12 & 0.4 & 17 & 0.4 & 30 & 17 \\
\hline 7 & B & Thorntree & 4 & 0.1 & 11 & 0.3 & 15 & 0.4 & 29 & 19 \\
\hline 8 & $\mathrm{~B}$ & Netherfields & 5 & 0.1 & 10 & 0.3 & 15 & 0.4 & 32 & 25 \\
\hline 9 & B & Pallister Park & 4 & 0.1 & 13 & 0.4 & 17 & 0.5 & 23 & 13 \\
\hline 10 & B & Berwick Hills & 3 & 0.1 & 12 & 0.4 & 15 & 0.5 & 21 & 14 \\
\hline 11 & $\mathrm{~B}$ & Park End & 3 & 0.1 & 12 & 0.3 & 15 & 0.4 & 21 & 15 \\
\hline 12 & $\mathrm{~B}$ & $\begin{array}{l}\text { Grove Hill and } \\
\text { Beechwood }\end{array}$ & 3 & $<0.1$ & 15 & 0.4 & 18 & 0.5 & 16 & 9 \\
\hline 13 & B & Winney Banks & 5 & $<0.1$ & 16 & 0.4 & 21 & 0.4 & 22 & 7 \\
\hline 14 & $\mathrm{C}$ & Hemlington & 2 & $<0.1$ & 11 & 0.3 & 13 & 0.4 & 18 & 12 \\
\hline 15 & $\mathrm{C}$ & Mandale & 3 & $<0.1$ & 15 & 0.4 & 18 & 0.4 & 14 & 7 \\
\hline 16 & $\mathrm{C}$ & Parkfields & 2 & $<0.1$ & 15 & 0.4 & 17 & 0.4 & 13 & 6 \\
\hline 17 & $\mathrm{C}$ & $\begin{array}{l}\text { Eastbourne and } \\
\text { Ragworth }\end{array}$ & 2 & $<0.1$ & 11 & 0.3 & 13 & 0.3 & 14 & 8 \\
\hline 18 & $\mathrm{C}$ & Blue Hall & 2 & $<0.1$ & 14 & 0.3 & 16 & 0.3 & 14 & 7 \\
\hline 19 & $\mathrm{C}$ & Hardwick & 1 & $<0.1$ & 6 & 0.1 & 7 & 0.2 & 18 & 12 \\
\hline
\end{tabular}

*Zone: $\mathrm{A}=$ near; $\mathrm{B}=$ intermediate; $\mathrm{C}=$ far. 
Table 6 Comparability of study areas in zones $A, B$, and $C$ and living circumstances (\%)

\begin{tabular}{|c|c|c|c|}
\hline & \multicolumn{3}{|l|}{ Zone ${ }^{\star}$} \\
\hline & $A$ & $B$ & $C$ \\
\hline Respondents (n) & 1539 & 1464 & 1485 \\
\hline \multicolumn{4}{|l|}{ Socioeconomic characteristics: } \\
\hline \multicolumn{4}{|l|}{ Unemployment: } \\
\hline Men & 30 & 32 & 33 \\
\hline Women & 12 & 15 & 14 \\
\hline No access to a car & 45 & 53 & 51 \\
\hline $\begin{array}{l}\text { Population stability, same address } \\
\text { for most of life }\end{array}$ & 57 & 58 & 59 \\
\hline \multicolumn{4}{|c|}{ Occupational exposure: } \\
\hline \multicolumn{4}{|c|}{ Worked in dusty industry for most of working life: } \\
\hline Men & 31 & 28 & 23 \\
\hline \multirow{2}{*}{\multicolumn{4}{|c|}{ Smoking history: }} \\
\hline & & & \\
\hline \multicolumn{4}{|l|}{ Current smokers: } \\
\hline Men & 37 & 39 & 35 \\
\hline Women & 35 & 43 & 45 \\
\hline \multicolumn{4}{|c|}{ Duration of years smoked (smokers only): } \\
\hline Men & 28 & 27 & 24 \\
\hline Women & 24 & 24 & 24 \\
\hline \multicolumn{4}{|l|}{ Indoor air pollution exposure: } \\
\hline Gas cooker & 73 & 69 & 74 \\
\hline Gas or coal fire & 42 & 40 & 48 \\
\hline \multicolumn{4}{|c|}{ Causes of worry or stress over past year: } \\
\hline Air pollution & 26 & 10 & 8 \\
\hline Smells outside & 17 & 6 & 4 \\
\hline
\end{tabular}

*Zone: $\mathrm{A}=$ near; $\mathrm{B}=$ intermediate; $\mathrm{C}=\mathrm{far}$

circumstances including surrogate indicators for occupational exposure, indoor air pollution, and perception of environmental pollution. The occupational experience of working in dusty industries varied for men, but not for women. Data on levels of smoking, and heating and cooking methods provided indirect indicators of indoor air pollution. Levels of smoking were similar across the zones. For pollution from heating and cooking, differences were found, but gradients were not in line with the study hypothesis of an exposure gradient near $>$ intermediate $>$ further. A steep gradient was found for the contemporary level of worry about air pollution and smells, with highest levels in zone A closest to industry.

\section{Discussion}

With proximity of residence to industry as the basic design feature for assessment of exposure we have attempted to verify and validate the suitability of the area choices to reflect a suspected exposure gradient across zones so that near >intermediate $>$ further. Our discussion centres around the five criteria outlined in the introduction.

HAVE WE BEEN ABLE TO CHARACTERISE THE TEMPORAL AND SPATIAL PATTERN OF EXPOSURE IN OUR STUDY AREAS?

Despite considerable effort we succeeded only in creating a jigsaw puzzle of community exposure with several of the pieces missing. However, a consistent pattern emerged. The evidence showed that residential exposure in areas close to industry has been and possibly still is, greater than in areas further away from industry. In particular zone A had higher exposures both in the past and in the present than did zones B or C. There was no indication that any of the boundaries of zone A should have been different to avoid misclassification of exposure. The hypothesised exposure gradient across Teesside was less clear cut for boundaries between zones $\mathrm{B}$ and $\mathrm{C}$ and north of the river Tees between zones $\mathrm{A}$ and $\mathrm{C}$. One estate (area 16, Parkfields) might have been better included in zone A than in C.

The limited available data on smoking and use of fuels did not indicate a gradient in indoor air pollution indicting residential exposure in the hypothesised direction. Any variation in indoor pollution was therefore unlikely to explain a gradient in exposure to industrial air pollution in the direction $\mathrm{A}>\mathrm{B}>\mathrm{C}$.

Although the overall trend in smoke and sulphur dioxide concentrations was dominated by the expected downward trend the data also suggested that this decline lagged behind the overall trend in those areas closest to industry. Because historical monitoring techniques for smoke were based upon the black staining of filters, appropriate for pollution dominated by combusted coal, the contribution of traffic to the long term trend over time was not easily documented. A key finding from dispersion modelling was that contributions from industry varied across the study area whereas contemporary contributions from non-industrial sources showed only limited variation.

HAVE WE BEEN ABLE TO DISENTANGLE INDUSTRIAL SOURCES FROM OTHER POLLUTION? Although historical documents consistently indicated industrial contributions as common knowledge, the contemporary contribution of industrial emissions was much harder to document. The strongest evidence in favour of a continuity of industrial contributions came from dispersion modelling, whereas the monitoring data carried messages of similarity rather than differences across the study area. Modern real time monitoring has improved the temporal resolution of data, but spatial resolution is now poor and predictions of spatial patterns have to be largely based on back trajectory analysis. The only state of the art monitoring site currently operating in Teesside is located in zone B.

Overall, it has been easier to assess the contributions of industrial pollution across the area historically than now due to the limited spatial resolution of current monitoring.

HAVE DIFFERENT METHODS OF ASSESSMENT OF EXPOSURE COMPLEMENTED ONE ANOTHER TO DRAW AN OVERALL PICTURE?

Both monitoring and modelling of air pollution were able to provide information on single pollutants. Although dispersion modelling can lead to a circular argument in the attribution to point sources, monitoring data supported the findings of modelling. Monitoring data on the other hand did not allow a detailed analysis of the levels of spatial resolution, but this was available from dispersion modelling. Exposure assessment by proximity to industry, the historical land use survey and the annual reports of the medical officer of health dealt with exposures to industrial pollutants more generally. If we had used other methods of exposure assessment-for example biological indicators, we would have been able to capture 
recent exposures (days, weeks) in more detail, but would still have been unable to capture exposures to unknown mixtures of pollutants of 20 or 30 years ago. We concluded that a range of exposure assessment methods was both essential and enabled us to build up a picture of historical and contemporary exposure.

HOW MUCH HAVE DATA SHOWN ABOUT TRUE

EXPOSURES OF POPULATIONS IN THE PAST?

With exposure assessment in epidemiological studies we attempt to get as close as possible to the true exposure of populations, avoiding exposure misclassification and other biases. The questionnaire survey highlighted the strong effect of sex with large differences in the proportion of men and women who worked in dusty industries. Historical documents pointed to the importance of variations in employment rates. During the 1980s the direct link between residence and employment was weakened with those working in heavy industry tending to commute from further away. We would argue that male exposure to air pollution in the past would have been dominated by occupational rather than residential exposure, whereas today residential exposure is more likely to dominate. By contrast women's past as well as contemporary exposure is likely to be dominated by residential proximity to industry. The available data on contemporary indoor air pollution did not indicate higher concentrations in areas near industry in Teesside. However, no data were available on heating and cooking patterns in the past. Overall therefore, for women the relative contribution of industrial emissions to their total exposure is likely to have been considerably greater than for men.

WAS THE INITIAL ASSUMPTION AND DESIGN

AROUND PROXIMITY OF INDUSTRY AS A

SURROGATE FOR RESIDENTIAL EXPOSURE

VINDICATED?

We suggest that the use of proximity of residence to industry is a defensible surrogate for true exposure of the community. The choice of areas was generally supported by other sources of information on exposure. In particular the neighbourhoods assigned to zone A seemed to be justified. At the same time the boundaries between the intermediate and further zones were less clear. The evidence suggested that three of the 19 estates (in zones B and C) may have been mis-allocated. A recent study with the proportion of land used by industry per ward as a proxy for industrial air pollution found that after controlling for socioeconomic deprivation a greater proportion of industrial land use was associated with higher mortality. ${ }^{40}$ Residential proximity was the only method that allowed matching on socioeconomic factors thereby accounting for the major contributors to ill health at the design stage. Monitoring and dispersion modelling data indicated variations in pollution which were compatible with the idea of land use and proximity being surrogates for exposure.

We do not know how feasible the comprehensive data collection we were able to use here would be elsewhere. The picture of ambient air pollution was more than the sum of its component parts. We used residential proximity to industry as the initial method of assessing exposure. With this approach in otherwise socioeconomically matched areas to assess exposure of populations near industry has the advantage that boundaries can reflect complex information from other data sources such as historical land use and employment patterns. Yet, proximity did not allow us to measure exposure. But the integration of measurements from many different sources made it feasible to assemble a picture of community exposure that verified the assumptions implicit in the use of proximity.

The contributions of Ann Rooke and Paula Rutter in providing the maps, Lesley Sharpe for the dispersion modelling, Debbie Nash for the land-use survey, and Jeff Duffield, Catherine Hall, Jim Longstaff, Anthony Luke, David Sutherland, and Jacqui Tate for contributions to the chapter containing environmental data in the TEES report are gratefully acknowledged. Funding was received from Middlesbrough Borough Council (City Challenge), South Tees Health Authority, Cleveland Family Health Services Authority, Cleveland County Council, and Northern and Yorkshire Regional Health Authority.

1 Katsouyanni K, Pershagen G. Ambient air pollution exposure and cancer. Cancer Causes Control 1997;8:284-91.

2 Steenland K, Savitz D. Future trends in environmental epidemiology. In: Steenland K, Savitz D, eds. Topics in environmental epidemiology. Chapel Hill: Oxford University Press,

3 Armstrong B, White E, Saracci R. Principles of exposure measurement in epidemiology. Oxford: Oxford University Press, 1994

4 Brunekreef B. Exposure assessment in environmental epidemiology. In: Bertollini R, Lebowitz M, Saracci R, et al, eds. Environmental epidemiology exposure and disease. Rome: Lewis, 1993:207-15.

5 Seifert B. Validity criteria for exposure assessment methods. Sci Total Environ 1995;168:101-7.

6 Wacholder S. When measurement errors correlate with truth: surprising effects of non-differential misclassification. Epidemiology 1995;6:157-61.

7 Jolley D, Jarman B, Elliott P. Socioeconomic confounding. In: Elliott P, Cuzick J, English D, et al, eds. Geographical and environmental epidemiology: methods of small area studies. Oxford: Oxford University Press, 1992:115-24.

8 Pless-Mulloli T, Phillimore P, Moffatt S, et al. Lung cancer, proximity to industry, and poverty in northeast England. proximity to industry, and poverty in nor

9 Friends of the Earth. Pollution injustice. http:// Friends of the Earth. Pollution injustice.

10 Wwilkinson P, Thakrar B, Shaddick G, et al. Cancer incidence and mortality around the Pan Britannica Industries pesticide factory, Waltham Abbey. Occup Environ Med 1997;54:101-7.

11 Elliott P, Martuzzi M, Shaddick G. Spatial statistical methods in environmental epidemiology: a critique. Stat Methods Med Res 1995;4:137-59.

12 Dolk H, Elliott P, Shaddick G, et al. Cancer incidence near radio and television transmitters in Great Britain. II. All high power transmitters. Am F Epidemiol 1997;145:10-7.

13 Kleinschmidt I, Hills M, Elliott P. Smoking behaviour can be predicted by neighbourhood deprivation measures. $f$ Epidemiol Community Health 1995;49(suppl 2):S72-7.

14 Diggle P, Elliott P. Disease risk near point sources: statistical issues for analyses using individual or spatially aggregated data. F Epidemiol Community Health 1995;49(suppl 2): S20-7.

15 Bhopal R, Moffatt S, Phillimore P, et al. Does living close to a constellation of industries impair health? A study of health, illness and the environment in north east England. health, illness and the environment in
Occup Environ Med 1998;55:812-22.

16 Lloyd O, Ireland E, Tyrrell $\mathrm{H}$, et al. Respiratory cancer in a Scottish industrial community: a retrospective case-control study. Fournal of the Society of Occupational Medicine 1986;36:2-8.

17 Teesside Environmental Epidemiology Study. Health, illness, and the environment in Teesside and Sunderland. Newcastle upon Tyne: University of Newcastle upon Tyne, 1995.

18 Richter B, Stickwell H. Descriptive study of deaths from cancer associate of residential proximity to the site of underground nuclear detonations. Arch Environ Health 1998;53:109-13.

19 Teesside County Borough Council. The health of Teesside during 1968. Teesside: Teesside County Borough Council Health Department, 1969.

20 Townsend P, Phillimore P, Beattie A. Health and deprivation: inequality and the north. London: Routledge, 1988.

21 Phillimore P, Morris D. Discrepant legacies: premature Phillimore P, Morris D. Discrepant legacies: premature
mortality in two industrial towns. Soc Sci Med 1991;33: mortality 
22 Phillimore P, Beattie A, Townsend P. Widening inequalities of health in northern England, 1981-91. BMF 1994:308: of health

23 Department of the Environment. National air quality information archive. http://www.aeat.co.uknetcen/aqarchive/ nonauto/sm/kjava1.html, 1996.

24 Anonymous. A report on the prevailing environmental conditions in the district of Eston and proposals for its improvement, 1974. Newcastle upon Tyne: Teesside County Borough Council, 1974

25 Derwent J, Dumitrean D, Chandler J. A preliminary analysis of hydrocarbon monitoring data from an urban site. Culham,
Oxfordshire OX14 3DB: AEA Technology, 1994. (AEA Technology Report CS 1835 8030/005.)

26 Stevenson K, Fernandes A. A study of hydrocarbon concentrations in the Middlesborough area. 1994. (AEA Technology Report CS 18325074.)

27 Campbell G. A survey of nitrogen dioxide concentrations in the UK using diffusion tubes London: The Stationery Office, 1991 .

28 Bertorelli V, Derwent D. Analysis and interpretation of air quality data for Middlesborough. Bracknell, Berkshire: Atmospheric Process Research Branch Meteorological Office, 1994

29 Medical Officer of Health. Eston MOH annual report. Eston, Teesside: Eston Urban District Council, 1921.

30 Medical Officer of Health. Eston $\mathrm{MOH}$ annual report. Eston, Teesside: Eston Urban District Council, 1956.
31 Medical Officer of Health. Eston $\mathrm{MOH}$ annual report. Eston, Teesside: Eston Urban District Council, 1958.

32 Medical Officer of Health. Eston $\mathrm{MOH}$ annual report. Eston, Teesside: Eston Urban District Council, 1963.

33 Medical Officer of Health. Stockton MOH annual report. Stockton, Teesside: Borough of Stockton, 1964.

$34 \mathrm{MOH}$, Medical Officer of Health, Stockton MOH Annual Report. Stockton, Teesside: Borough of Stockton, 1967.

35 Stevenson K, Fernandes A. A study of hydrocarbon concentrations in the Middlesborough area. 1994. (AEA Technology Report CS 18325074.)

36 House J, Fullerton B. Teesside at mid century. An industrial and economic survey. London: Macmillan, 1960.

37 Reader C. Analysis of air pollution readings for Cleveland 1972-81: report for the committee for the co-ordination of air pollution and noise, report about air pollution for the period 1972-1981 based on 53 sites. Cleveland: Cleveland County Research and Intelligence Unit, 1982.

38 Gillham C, Leech P, Eggleston H. UK emissions of air pollutants 1970-90. Stevenage, Hertfordshire: Warren Spring ants 1970-90. Stevenage, Hertfordshire:
Laboratory, 1992. (Report No LR997 (AP).

39 Williams M. Atmospheric dispersal of pollutants and modelling of air pollution. In: Harrison R, ed. Pollution: causes, effects, control. Cambridge: Royal Society of Chemistry, 1990:201-20.

40 Sainsbury P, Hussey R, Ashton J, et al. Industrial atmospheric pollution, historical land use patterns and mortality. F Public Health Med 1996;18:87-93.

\section{Vancouver style}

All manuscripts submitted to Occup Environ Med should conform to the uniform requirements for manuscripts submitted to biomedical journals (known as the Vancouver style.)

Occup Environ Med, together with many other international biomedical journals, has agreed to accept articles prepared in accordance with the Vancouver style. The style (described in full in the $\mathcal{F} A M A[1]$ ) is intended to standardise requirements for authors, and is the same as in this issue.

References should be numbered consecutively in the order in which they are first mentioned in the text by Arabic numerals on the line in square brackets on each occasion the reference is cited (Manson[1] confirmed other reports[2][3][4][5]). In future references to papers submitted to Occup Environ Med should include: the names of all authors if there are three or less or, if there are more, the first three followed by et al; the title of journal articles or book chapters; the titles of journals abbreviated according to the style of Index Medicus; and the first and final page numbers of the article or chapter. Titles not in Index Medicus should be given in full.

Examples of common forms of references are:

1 International Committee of Medical Journal Editors. Uniform requirements for manuscripts submitted to biomed jo

2 Soter NA, Wasserman SI, Austen KF. Cold urticaria: release into the circulation of histmaine and eosinophil chemotactic factor of anaphylaxis during cold challenge. $N$ Engl ₹ Med 1976;294:687-90.

3 Weinstein L, Swartz MN. Pathogenic properties of invading micro-organisms. In: Sodeman WA Jr, Sodeman WA, eds. Pathologic physiology, mechanisms of disease. Philadelphia: W B Saunders, 1974:457-72. 